大阪大学畨学部 (土任：弓倉教授）と医学部，第 1 解剖学教室（主任：高木教授).

Dental School (Director: prof. S. YUMIKURA) a.

Ist Dept. of Anat. of Med. School (Director: Prof. K. TAKAGI), Osaka Univ.

耳下腺內分泌汇関する細胞學的研究.

III. 策萄糖負荷試驗.*

\title{
Cytological Studies on Endocrine Secretion of the Parotid Gland.
}

III. On the Effects of the Glucose Injection.

本城 登 Noboru HONJYO.

〔昭和 28 年 8 月 13 日原稿受付.〕

余は襄につロキサン（以下「ア」と畧す）の注射によって料尿を起させ た家鬼耳下腺を，日数を追って細胞学的飞観察した処，栯尿40一50日飞至 ると耳下腺終末部及び分泌管上皮の細胞飞内分泌機能を想像させるような 特巽像が現われることを認めた。即ち夫々の細胞基感部に巨大な空胞を多 数抱有し，ため飞原形質は核と共飞細胞先端へ押しやられる。斯る空胞は 正常耳下腺には全く認めることは出来ない，又余は犬について荟蔵の全摘 出を行ったところ，6-8 日後には耳下腺に上述の家鬼の場合と全く同様の 空胞が現われることを確認した。從って斯る巨大空胞の出現は糖尿に由来 したものと見做してよいと信ぜられる，他方高阊によれば糖尿時の耳下腺 は，膵 Langerhans 氏䲶の機能を代償すると言われているから，余の観察 した耳下腺細胞の巨大空胞は血糖を下降せしめる所謂インシュリン様の物 質を内容としているのかも知れないと思われる。然し組胞内空胞が蓄積 していると言う将的所見のみではとを論ずることは出米ないので，余は粘 尿時に更に血糖を上昇せしめるが如き処置を施した豩合，該主大空胞が消 長を示すか否かを確めたいと考光た。之れ本研究を企図した所以である.

\section{I. 研究材料と方法.}

コダック会社製のフロキサンを使用し，これをプロキロ $200 \mathrm{mg}$ の割合で 体重 $2.5 \mathrm{~kg}$ 前后の健承雄性:家婜の耳静脉に注射した.「ア」注射後に屢々起 る一過性の高度低血糖症を予防与るため,「て」注射後は 2 時間間隔で $20 \%$

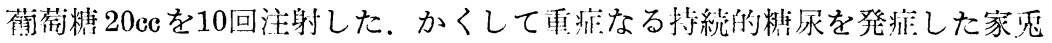

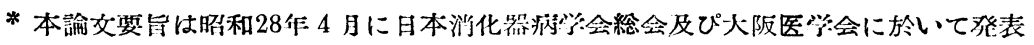
した。 
を50日間飼育し，最終給食后24時間を経て血糖を省しく上昇せしめる目的 で，50\%葡萄糖 $20 \mathrm{cc}$ (以下「ブ」と畧す）を耳腈脉より注射した，而して 「ブ」注射后 5 分より 30 時間に互り 12 段階飞分って开下腺小片を取り, 前 諸篇に記載したと同様の方法により固定及び染色して標本を作成した。

\section{II. 所見.}

「ブ」注射后 5 分より 30 洔間飞至る 12 段階。(5，15，30分，1，1.5，2，2.5， $3 ， 6 ， 12 ， 24 ， 30$ 時閌）の各例所見を羅列することは煩倠であるので，之を 省畧して綜合的飞記述する。

\section{A. 腺終末部細胞.}

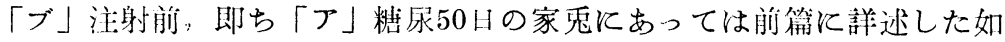
く，細胞は胞体下半部に大空胞を充満し，原形質は核と其飞細胞先端へ押 し上げられたかの如き観を呈する。このため腺終末部断面は外半部が透明 州によって井まれた像を星する。而して細胞先端に集まっている原形質中 には分泌顆粒が認められ，又明最をるって用まれた顆粒もここに存する。 他方 plastosomes (pl.) は顆粘の多い細胞飞あっては殁どこれを認めないが， 顆粒の少いものでは顆粒状，亜鈴状，桿状をなして pl. が核凮囲に認めら れる (Fig. 1). 従って斯る細胞は姴すると正常細胞の基底部に大空胞が蓄 積したものであって，変州其他によって斯くなったものでないことは明か である．然るに「ブ」を注射すると，細狍底の巨大空胞は注射后 5 分飞て 早くもその人部分が消尖し，火空肘の遗残と見られる小空犯を組胞底部に 少数有する紐胞（Fig. 2) が散見せられるに過ぎなくなる．この傾问は急 速に進展し 30 分後になると最早や紏胞底には仓く空胞を見ることは出来な い. 他方細胞底の空胞消失と其飞原形質は胞体全面飞拨がり，核は細胞底 飞近く移動し，又細胞上半部は分泌顆粘或は分泌空胞が占めるようになり， かくて細胞は全く正常構造を再現する。爾後 6 時間飞至る迄は細胞は或は 分泌顆粒を，或は分泌空胞を以て充満し，いづれも正常機能の一段階像を 呈し（Fig. 3 と 4)，細胞底江空胞を全く見ない。処が 6 時間を過ぎると細 胞底に少数ながら空胞が現われ (Fig. 5)，注射前の状態にかえるかに兒え るが，12時䦌，24時間では再び空狍は僅少となり容易飞見出せない。然し 30 時間後になると多くの細胞が小空胞を細胞底滰䅡し，又可成り大なる 空胞を有するものも稀ではなく，6時間后の所見に比すると滛かに注的抔 の像に汇い (Fig. 6).

之を要与るに「ア」糖㽷によって睍われた細胞底の空胞は,「ブ」注射后 速かに消犬し，後 6 時䦗にて一特蓄樍され始めるかに見えるが，再び消失 
し，30時間を経た項「ブ」注射前の状態と復帰する。この間胞体は或は分 泌颗粒にて充満し, 或は分泌空胞飞て占められるが, 之等は其飞正常機能 像の一段階像飞他ならない。このよう飞細胞呧の空胞像は注射后時間を迎 って動きを示する，pl. は「ブ」注射前と変りなく，桿状，連鎖状，亜鉿 状, 顆粒状等各種の形を呈し, 機能の一般飞平静なるを物語っている.

\section{B. 分泌管上皮細胞.}

「ブ」注射前の細胞構造は前篇にも記載した如く甚だ興味ある特買像を 呈する. 即ち原形質は一般飞暗調で，正常時飞兒られる細胞先端の明調部 は存せず，核は細胞先端飞近く位しその周囲飞多くの粗大顆粒が配列する. 胞体の下半部はすへて大空胞によって占められ，ため飞本上皮特有の縱線 構造はその根跡さえも認めることは出来ない (Fig. 7). 然ると「ブ」を注 射すると，細胞下半部の大空胞は間もなく消失する．これと同時飞原形質 はひろがり，細胞底部には粗大顆粒が多く集まるが，これらは正常細胞の 如き美麗なる縱線を形成することがない，但し粗大顆粒は細い淡染性の糸 状体で貫かれて恰も連珠状を呈するものが少くない。そのほか細胞底には 時及小空胞を認め, 或は又胞体中央飞移動した核飞接して半月状の空胞が 見られる (Fig. 8). 斯る空胞は「ブ」注射后 1 時間迄は認められるが，そ の後は発見困難である。爾後 24 時間までは細胞構造飞著変を見ず，胞体上 半部は概ね正常機能像を呈し, 核上部の顆粘が数に於いて多少動摇を示す のみである。 また胞体下半部では粗大顆粒が或は散在性飞, 或は不著明な がら連珠状を呈しているが，決して典型的の縱線構造を再現することなく， 正常細胞のこの部に見る機能像とは趣を異にする (Fig. 9). 然るに30時間 後になると大空胞が細胞底部を占領し，核は細胞先端飞近く移動して「ブ」 注射前飞相似の像を呈する (Fig. 10).

以上述べたる如く分泌管上皮にあっては, 細胞成の大空胞は「ブ」注的 后問もなく大部分が消失し， 1 時間以后には全く認められない。然るに24 時間后より空胞は再び細胞底に蓄積を始め，30時間後には大約「ブ」注射 前の状態とわ兄る。

\section{III. 考 察.}

以上耳下腺終末部及び分泌管上皮の細胞所見から明かな如く,「丁」煻尿 50日にして細胞底涀われた巨大空胞は「ブ」を注射すると間るなく消失 し，30時間後には再び細胞底沉現われる，その途中に於いて終末部では注： 射後 6 時間飞多少の空胞が現われるが，蓄積飞至らずして消失する。これ 飞反し分泌管上皮ではかかる一侍的の然胞山現は見られないが，空胞新生 
の直前状況は認められる.

斯る所見より推察すると，1.「ブ」注射㷙蓄積されて居た空胞内容は， 「ブ」注射によって放出し尽されること，2，そして放出後は細胞底部に於 て斯る物質の新生が営まれているが，放出と新生が恐くは同程度であるた め縕胞底飞蓄積される暇のないこと，3.30時間後に於いて初めて新生が放 出を上备るようになる結果，細胞底に多くの空胞が出現することの 3 事笋 が考えられる．即ち余の最も確めたいと考劣ていた細胞戍に於ける巨大空 胞の消長の有無は，終末部及び分泌管上皮ともに明かに「有」であること が知られ，又消與の経過は网者に於いて大善のないことが判ったわけであ る.

細胞学的所見より血糖の変動に眼を転ずると，此所でも又興味ある成績 飞接する。即ち「フ」糖尿50日の家鬼に「ブ」を注射し，注射前より注射

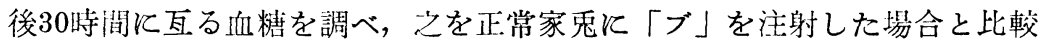
汹示したのが次の网である。

「「厂」料尿家鬼「ブ」負荷成 績.

\begin{tabular}{|c|c|c|c|c|c|c|c|c|c|c|c|}
\hline \multirow{2}{*}{ 検査時期 } & \multicolumn{4}{|c|}{ 血 } & \multicolumn{3}{|l|}{ 糖 } & \multicolumn{4}{|c|}{$(\mathrm{mg} / \mathrm{dl})$} \\
\hline & 前 & $30^{\prime}$ & $1^{\circ}$ & $1^{\circ} 30^{\prime}$ & $2^{\circ}$ & $2^{\circ} 30^{\prime}$ & $3^{\circ}$ & $6^{\circ}$ & $12^{\circ}$ & $24^{\circ}$ & $30^{\circ}$ \\
\hline $\begin{array}{l}\Gamma \text { 厂泩 } \\
\text { 糖尿 }\end{array}$ & $\begin{array}{r}98 \\
321\end{array}$ & & & & & $\begin{array}{r}95 \\
550\end{array}$ & $\begin{array}{r}94 \\
542\end{array}$ & $\overrightarrow{520}$ & $4 \overline{60}$ & $\overline{349}$ & $\overrightarrow{320}$ \\
\hline$\lceil>」$ & 298 & & & & & & & $\overline{480}$ & $\overline{420}$ & 340 & $2 \overrightarrow{96}$ \\
\hline $\begin{array}{l}\Gamma \text { 浙 } \\
\text { 糖尿 }\end{array}$ & & & & & & $\begin{array}{l}119 \\
645\end{array}$ & $\begin{array}{l}126 \\
642\end{array}$ & $\overline{638}$ & $\overrightarrow{485}$ & $\overline{380}$ & $3 \overline{323}$ \\
\hline $\begin{array}{l}\Gamma ア \text { 泩射前 } \\
\text { 糖尿 } 50 \text { 日 }\end{array}$ & $\begin{array}{r}92 \\
286\end{array}$ & & & $\begin{array}{r}97 \\
602\end{array}$ & $\begin{array}{r}99 \\
687\end{array}$ & $\begin{array}{r}95 \\
577\end{array}$ & $\begin{array}{r}94 \\
594\end{array}$ & $\overline{553}$ & $\overline{411}$ & $\overline{302}$ & $\overline{267}$ \\
\hline $\begin{array}{l}\Gamma>\text { 泩射前 } \\
\text { 糖原 } 50 \text { 日 }\end{array}$ & $\begin{array}{r}98 \\
299\end{array}$ & $\begin{array}{l}26 \\
50\end{array}$ & & 564 & & $\begin{array}{l}108 \\
544\end{array}$ & 580 & $\overline{508}$ & $4 \overrightarrow{65}$ & $\overline{365}$ & 281 \\
\hline $\begin{array}{l}\lceil ア 」 \text { 泩射前 } \\
\text { 糖尿 } 50 \text { 日 }\end{array}$ & $\begin{array}{l}102 \\
394\end{array}$ & & & & & 506 & $\begin{array}{r}92 \\
592\end{array}$ & $\overline{530}$ & $\overline{448}$ & $\overline{400}$ & $\overline{400}$ \\
\hline 平健康 & $\begin{array}{l}106 \\
320\end{array}$ & $\begin{array}{l}235 \\
560\end{array}$ & $\begin{array}{l}150 \\
581\end{array}$ & $\begin{array}{l}117 \\
555\end{array}$ & $\begin{array}{l}114 \\
563\end{array}$ & $\begin{array}{l}107 \\
543\end{array}$ & $\begin{array}{l}103 \\
564\end{array}$ & $\overline{554}$ & $\overline{448}$ & $\overline{356}$ & 315 \\
\hline
\end{tabular}

即ち罒に見る如く栯尿家㣻に於いて血精が高いことは当然であり，又「ブ」 注射后の高血精が注射前の血椨飞同復する経過が，正常例飞比して誠飞遅 そとしていることは，既飞多くの人達によって認められ，いつれも糖処理 機能の障碍として説咐されている（Elliassow 1922，Noorden 1927，林1929， 


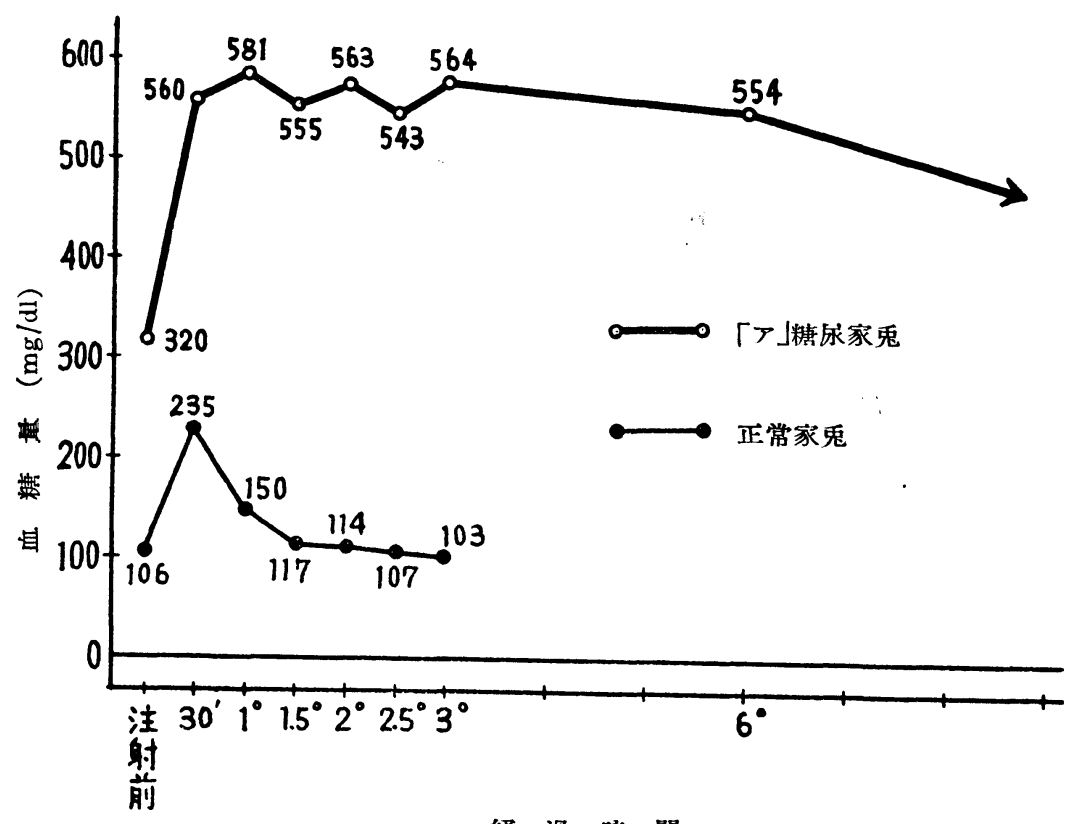

経 過 時 間

黑川 1951, 竹田 1951, 阔本 1951, 福本 1952等). 此処に余が興味を惹く のは「ア」糖尿家鬼の血糖值と耳下腺細胞底の空胞の消長との間に見られ る相互関係である。即ち「ブ」注射后 1 時間として血糖は最高值に達する が，細胞底空胞はこの間に全く消失する．血糖值は 6 時間後より下降の傾 向を示すが，此時終末部細胞底には若干の空胞蓄積があり，血糖值が注射 前の值に回復する30時間後では紐胞底には多くの空胞が蓄積せられ，注射 前の状態に近い，斯の如く血啸值が完全に旧值に復帰するまでは細胞底に 空胞の出現することは殆んどないが，他面細胞底に於ける空胞新生への動 きは前述の如く明かに認めることが出来る．従って細胞底の空胞は血䊀を 下降せしめるか, 少くとも血糖の上舁を抑える方向に作用する物質を内容 としていることが信ぜられる。而してこれらの物質は細胞底に於いて新生 されることは最早疑うべくもない。

高岡は内科学的観察から糖尿時には耳下腺が脺 Langerhans 氏岛の機能 を代償すると言っているが，余の成績は正しくそれを証明するすのと信じ てよく，終末部及び分泌管上皮の各細狍が斯る代償作用を有する物質を内 分泌すると言うことが出来る。しかし終末部細胞底の空胞と分泌管上皮細 胞瓦の空胞とは畧々同㥞の消長を示すが，それが敌にその内容が同一物質 であるとは決定出来ない。 


\section{IV. 總 括的結 語.}

「フ上糖尿家嵬耳下腺にあっては終末部及び分泌管上皮の細胞底部に大 空胞が出現するが，この空胞は「ブ」を耳静脉より注射すると間もなく消 失し 30 時間後に再び現われる。との間小空胞の出現或は消失があるが，著 明ではない，又分泌管上皮細胞底部飞於ける pl. 性顆粒は常飞空胞新生飞 向って活動していると考えられる

「ブ」注射前及び注射后の血糖值と細胞底空胞の消長とを比較すると， 血糖値の高い時には細胞底に空胞は見られず，低くなるに及んで空胞が現 われる。

以上の成績から，血糖が上昇している間は空胞内容は旺んに消費せられ るために, 細胞内では新生せられるにも拘らず蓄積する睱なく, 放出せら れ，血糖が下ると消費が少なくなり，新生された物質は細胞底へ蓄積され るものと解することが出来，この空胞内容が血糖を下降せしめる物質乃至 は少なくとも血糖上昇を抑制せんとする物質であるととが信ぜられる。

稿を終るに臨み，恩師高木教授及び和歌山医大藤江助教授の御慜篤な御指導と精 緻な御校閲を感謝すると共に，恩師弓倉教授の御唓摓を謝す。

\section{Author's Abstract.}

It was previously demonstrated that the giant vacuoles appeared in the basal portion of both the gland cells and the epithelial cells of the secretory duct of the rabbit's parotis which were put into alloxan-diabetes.

These vacuoles disappear soon after the intravenous injection of glucose and reappear in the same portion after 30 hrs.

During 30 hrs. small vacuoles reappear and disappear, but it is not remarkable, the plastosomes in the epithelial cell base are always active form which seems to produce the vacuoles.

In the comparison of the movement of the giant vacuoles and the value of blood-sugar. there can be seen a inversive relationship between them: when the value of blood-sugar is high, the cell has no vacuoles, when it is low, the vacuoles reappear in the cell base, therefore the author believes that the substance in the vacuoles is consumed during high blood-sugar, so it can not be accumulated in the cell base though it is produced in the cell, and when the value of blood-sugar becomes lower, the comsumption becomes inferior, the produced substance is accumulated in the cell base, then the vacuoles reappear.

Here the author can reach the conclusion that the substance contained in the giant vacuoles, is the one to descend blood-sugar or at least to control an ascension of blood-sugar. 
文献.

篇 5 に揭載。

\section{附 圖 說 明.}

附因は凡て Zeiss，obj. 100×，okl. 10×を用い，Abbe 氏描写器によって投影描 写した。

腺終末部細胞。

Fig. 1. 対照（アロキサン䊉层50日育飼のもの).

Fig. 2. 菊葡栯注射後 5 分.

Figs. 3 と 4. 同上. 30 分上り 6 時間まで.

Fig. 5. 同上. 6 時間.

Fig. 6. 同上. 30 時間.

分泌管上皮細胞.

Fig. 7. 対照（アロサキン糖尿50日飼育のむの).

Fig. 8. 葡萄淩注射後 30 分.

Fig. 9. 同.上. 1-24時間.

Fig. 10. 同上. 30 時間.

\section{Explanation of Plate.}

These figures are the reproductions obtained with ABBE's apparatus, all cell image are under the same magnification.

A. The gland cells of the rabbit's parotid.

Fig. 1. Control. 50 days feeding under alloxan-diabetes.

Fig. 2. 5 min. after the injection of glucose into the rabbit mentioned above (fig. 1).

Figs 3 and 4 . Same. 30 min. -6 hrs. after the injection.

Fig. 5. Same. 6 hrs. later.

B. The epithelial cells of the secretory duct.

Fig. 7. Control. same rabbit mentioned in fig. 1.

Fig. $8.30 \mathrm{~min}$. after the injection.

Fig. 9. Same. 1-24 hrs. later.

Fig. 10. Same. 30 hrs. later. 

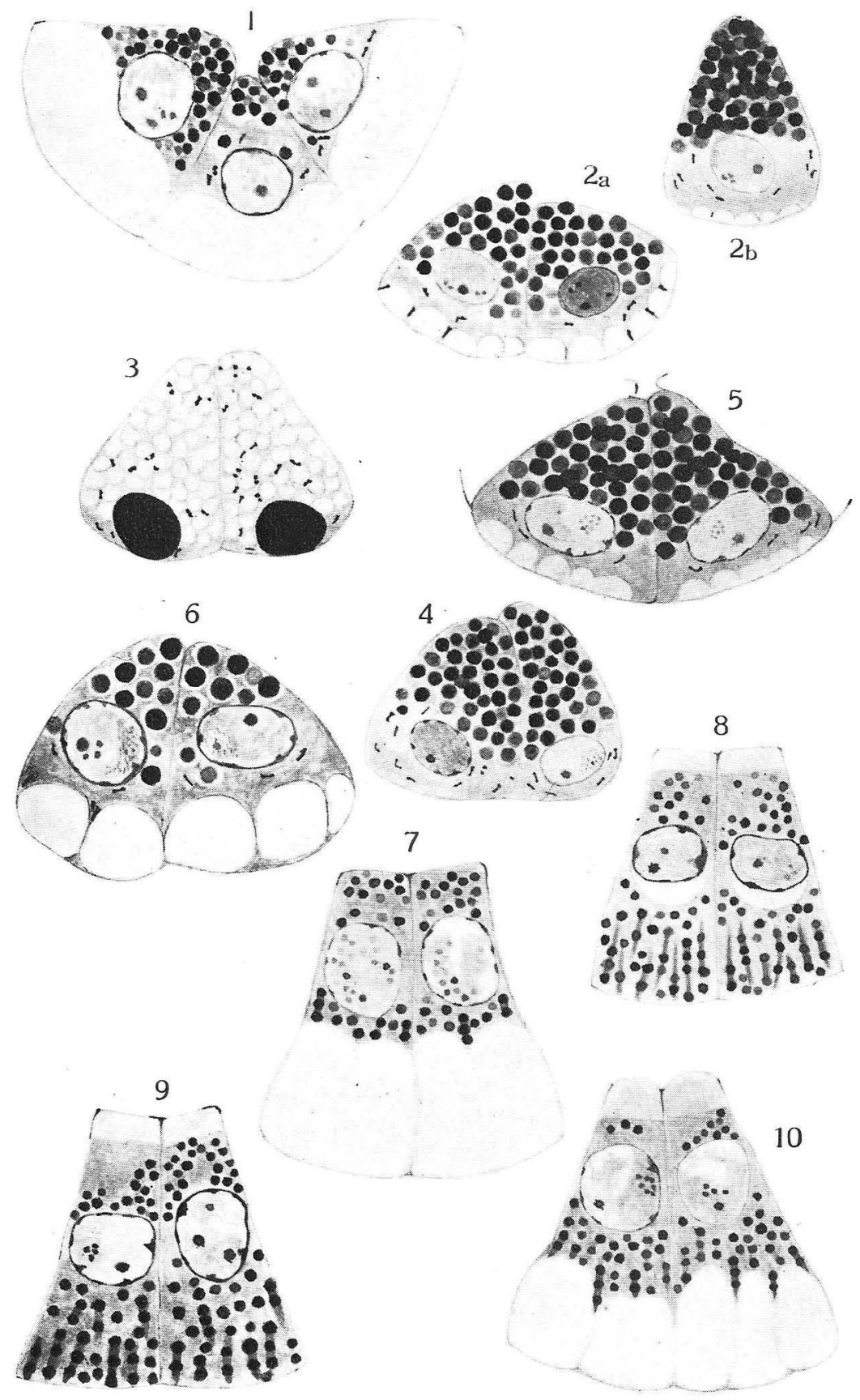